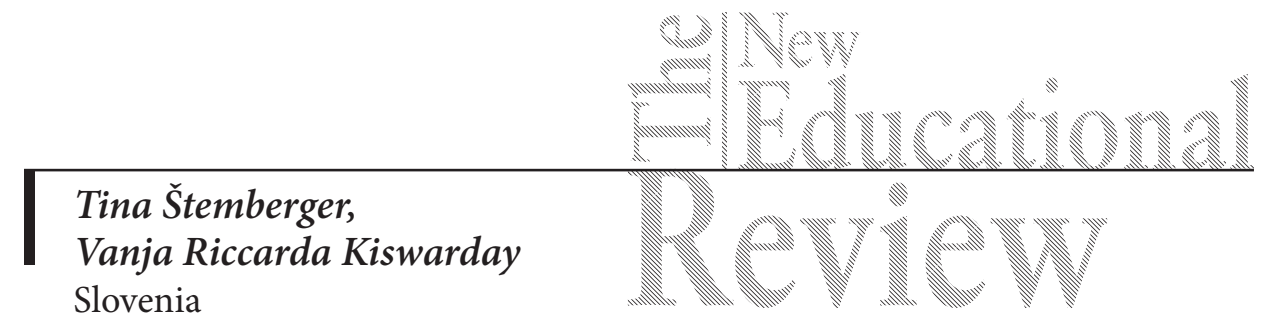

\title{
Validation of the Inclusive Competences Scale for Educators (InComSEdu)
}

DOI: $10.15804 /$ tner.2016.44.2.20

\begin{abstract}
The study aimed to construct and validate the Inclusive Competences Scale for Educators (InComSEdu). The basis for item generation was the "Profile of Inclusive Teachers", a document developed by the European Agency for Special Needs and Inclusive Education. Items were measured on a 5-point Likert scale. In order to test the validity and internal consistency of the scale, item analysis, exploratory and confirmatory factor analysis and Cronbach's a were used. On a sample of Slovenian educators factor analyses proved the InComSEdu had seven subscales: Team working and cooperation with others, Implementing knowledge about inclusive education and support, Reflecting on and learning from inclusive practice, Optimising challenges and approaching interdisciplinary, Accepting professional responsibility for each child's development, Promoting resilience and professionality, and Empowering children's life skills. Results indicate that InComSEdu is a valid and reliable instrument for the evaluation of inclusive competences among educators.
\end{abstract}

Keywords: preschool educators, inclusive competences, scale, factor analysis, internal consistency, validation

\section{Introduction}

During the last decades, inclusion as an educational approach has become fairly recognised and adopted all over the world. Inclusion and inclusive education are understood and interpreted in various ways. However, Ainscow (2005) strongly 
recommends compliance with four key elements that meaningfully delineate inclusion. Educationalists and education systems need to perceive inclusion as a process of constant searching and learning from one another and from different situations, and to sensitively identify and remove different kinds of barriers that prevent equal opportunities for presence, participation and achievement of all students, especially those who may be at risk of marginalisation, exclusion or underachievement (Ainscow, 2005). UNESCO (2009) states that real inclusion implies active participation, learning at the highest level and developing the potential of each individual (ibid., p.13).

It is clear that inclusive education embodies a wide variety of situations in which the teacher should act effectively with all children (Moran, 2009) and requires a cluster of teacher abilities, commitments, knowledge, and skills. Inclusion in its developmental and processional aspect is a responsibility of all teachers and teacher educators (Cook, 2002; Watkins, 2012). The broadness of the competences definition that encompasses attitudes, knowledge and skills gives a comprehensive framework to the competence-based approach in inclusive teacher education. Baráth (2013) defined these three broad headings as descriptors, giving to attitudes the motivational value knowledge, the informational value and skills the operational value. However, as Korthagen (2004) states, competences only represent a potential for behaviour, not the behaviour itself and it depends on various circumstances whether they are realised in practice or not. The question of how to efficiently implement inclusive education is still a big challenge among teachers and teacher educators. However, the continuous attempt to improve and foster pro-inclusive competences of teachers and student teachers seems to be common all over the world (Cencič, Istenič Starčič \& Borota, 2012; Cook 2002; Kim 2011; Lepičnik Vodopivec and Vujičić, 2010; Marinšek and Hmelak, 2015; Sharma et al., 2012; Winter, 2006).

The need for concrete information on the necessary inclusive competences required of all teachers working in inclusive settings stimulated the European Agency for Special Needs and Inclusive Education to specify and develop a Profile of inclusive teacher competences (Watkins, 2012). The areas of competence in the Profile are placed within a framework of four core values that are closely related to teaching and learning in inclusive education: i) embracing and valuing diversity of all learners, considering differences as a resource and an asset to education; ii) supporting all learners and having high expectations of all learners' achievements; iii) collaborating and team-working; and iv) taking engaged responsibility for continuing personal and professional development (Watkins, 2012).

In the last decade, many research studies have focused on teachers' attitudes toward some aspects of inclusion (MacFarlane \& Marks Woolfson, 2013; Mahat, 
2008; Rutar, 2012; Štemberger, 2013 Unianu, 2012), on attitudes in connection with self-efficacy (Cook, 2002; Forlin et al., 2009; Malinen, Savolainen, Xu, 2012; Weisel and Dror, 2006), and the impact of experience and self-efficacy on attitudes (Cook, 2001; Emam and Mohamed, 2011; Unianu, 2012). The attitudes have probably been in the focus due to the belief that successful implementation of inclusion mainly depends on teachers' positive attitudes towards children with special educational needs (Malinen, 2012). It is clear that teachers should hold a positive attitude towards inclusion, but they should be experts in the area as well, so their competences should also be the subject of research. Knowledge about how mainstream teachers perceive themselves as prepared and competent to teach and educate in inclusive settings would enable policy makers and teacher educators to prepare and empower future teachers to meet the needs of diverse learners and to provide the best educational environments for all children.

Research into any aspect of inclusion requires psychometrically sound instruments that allow researchers to respond to factors that may facilitate or impede the information and modification of inclusive competences. Various scales measuring some aspects of inclusion have been proposed and constructed over the years. In most of the cases, there has been a lack of information regarding both the instrument contents and psychometric properties (Mahat, 2008). Therefore, we wanted to construct a psychometrically sound instrument that would enable researchers to carry out research studies based on the valid and reliable instrument.

\section{The purpose of the study}

The purpose of the study was to construct and validate the Inclusive Competences Scale for Educators (InComSEdu).

\section{$\underline{\text { Research Methodology }}$}

\section{Sample}

The research sample consisted of 124 educators from all over Slovenia, all of whom were female. The majority (33.9\%) of the participants had 0-10 years of work experience, followed by those (27.4\%) with 31-40 years and those with 21-30 years (21.0\%) of work experience with preschool children. The smallest 
group within the sample was the group of preschool teachers (17.7 \%) with 11-20 years of work experience.

\section{Generating items for the Inclusive Competences Scale for Educators (InComSEdu)}

The basis of the InComSEdu was the Profile of Inclusive Teachers that was designed by international experts (European Agency for Special Needs and Inclusive Education 2012). Within the Profile they identified competences required of effective, inclusive teachers and represented the commonalities between policy and practice that should be included in teacher education for inclusion. The Agency states that the Profile in its non-copyright section is available for modifications and researchers are allowed to modify and develop the scale in order to meet a range of possible purposes (Watkins, 2012, p.9). Following that invitation, we customized the scale according to Slovenian national characteristics in preschool education. The questionnaire that was completed by the preschool teachers, consisted of 48 items, rated on a 5-point Likert scale, ranging from I strongly agree (5) to I strongly disagree (1), and one open-ended question (work experience).

\section{Data analysis}

For the initial 48 items, we first checked the correlation of each item with the total sum and the inter-correlation between items. The first analysis showed that 3 items were poorly linked with the total sum and were thus excluded from the further analysis. The inter-correlation analysis further indicated a poor correlation of additional 13 items. As a result, the final version of InComSEdu consists of 32 items. To check the validity of the InComSEdu, factor analysis (by prior check of KMO and Batlett's Test of Sphericity) was performed and Cronbach's alfa was employed to check the internal consistency.

\section{Results}

\section{Validity}

The three traditional forms of validity to look for are: (i) content validity, (ii) concurrent validity and (iii) construct validity (Creswell, 2014, p. 160). The content 
validity of the InComSEdu was established by following the items derived from the "Profile of Inclusive Teacher" (Watkins, 2012). Due to lack of similar instrument(s) we could not examine the concurrent validity. The construct validity was examined through factor analysis.

Prior to factor analysis, the Kaiser-Meyer-Olkin Measure of Sampling Adequacy (KMO) was checked and Bartlett's Test of Spehricity was analysed. The calculated KMO was .861, above the recommended valued of 0.6 (Field, 2005), which indicates that the factor analysis is appropriate for the data set. The results of Bartlett's Test of Sphericity was $\left(\chi^{2}=2237.381, \mathrm{df}=561, \mathrm{P}=.000\right)$, suggesting the factor ability of the correlation matrix (Field, 2005).

To determine the number of factors, Principal Component with Varimax rotation was performed - it suggested 7 factors solution. Items were retained when they exceeded +0.40 . The seven extracted factors explained $63 \%$ of variance. The first factor accounted for $36.89 \%$ of variance, which is above $20.0 \%$ and it indicates the appropriate construct validity of the scale (Field, 2005).

Table 1. Factor loading of the Inclusive Competences Scale for Educators

\begin{tabular}{lccccccc}
\hline \multicolumn{1}{c}{ Item } & $\mathrm{F}_{1}$ & $\mathrm{~F}_{2}$ & $\mathrm{~F}_{3}$ & $\mathrm{~F}_{4}$ & $\mathrm{~F}_{5}$ & $\mathrm{~F}_{6}$ & $\mathrm{~F}_{7}$ \\
\hline $\begin{array}{l}\text { Communication with parents needs to be } \\
\text { planned. }\end{array}$ & .837 & & & & & & \\
\hline
\end{tabular}

Partnership with families requires respecting $\quad .724$

their needs and including them in individu-

alized programme.

The interpersonal relationships between the .717 educators and parents have an impact on the child's achievement of learning goals.

The educator needs to be the bridge between $\quad .698$

the parents and other professionals helping

the child.

Inclusive education requires all educators to $\quad .631$

work in a team.

Educators need to be familiar with the ed-

.824

ucational acts and the legal context of their work.

Educators have to inform parents about the legal rights and the possibilities available for the better inclusion of the child.

Educators need to be oriented toward constant development of their knowledge and skills to improve inclusive practice. 


\begin{tabular}{|c|c|c|c|c|c|c|c|}
\hline Item & $\mathrm{F}_{1}$ & $\mathrm{~F}_{2}$ & $\mathrm{~F}_{3}$ & $\mathrm{~F}_{4}$ & $\mathrm{~F}_{5}$ & $\mathrm{~F}_{6}$ & $\mathrm{~F}_{7}$ \\
\hline $\begin{array}{l}\text { Inclusive practice often requires a resource- } \\
\text { ful (inventive) educator. }\end{array}$ & & .732 & & & & & \\
\hline $\begin{array}{l}\text { An educator is an equal team member in all } \\
\text { phases of the individual programme (plan- } \\
\text { ning, realizing and evaluating). }\end{array}$ & & .610 & & & & & \\
\hline $\begin{array}{l}\text { I find inclusive paradigm and working with } \\
\text { children with SEN as a great professional } \\
\text { challenge. }\end{array}$ & & & .821 & & & & \\
\hline $\begin{array}{l}\text { In the process of improving my inclusive } \\
\text { practice, I make use of observations made by } \\
\text { my colleagues. }\end{array}$ & & & .782 & & & & \\
\hline I learn a lot from the children with SEN. & & & .734 & & & & \\
\hline $\begin{array}{l}\text { I set goals to achieve a more inclusive and } \\
\text { effective learning environment. }\end{array}$ & & & .658 & & & & \\
\hline $\begin{array}{l}\text { Action research is an important tool in goals } \\
\text { oriented to individualised planning. }\end{array}$ & & & & .827 & & & \\
\hline $\begin{array}{l}\text { Some activities that were originally designed } \\
\text { for SEN proved effective for other children, } \\
\text { too. }\end{array}$ & & & & .771 & & & \\
\hline $\begin{array}{l}\text { The educator should know how to evaluate } \\
\text { his own work and effectiveness. }\end{array}$ & & & & .736 & & & \\
\hline $\begin{array}{l}\text { It is important for the educator to know } \\
\text { the roles of different professionals (speech } \\
\text { therapists, special pedagogues, inclusive } \\
\text { pedagogues, psychologists, etc.) }\end{array}$ & & & & .705 & & & \\
\hline $\begin{array}{l}\text { It is important for the educator to know the } \\
\text { cultural, ethical, linguistic and social back- } \\
\text { ground of the families. }\end{array}$ & & & & .704 & & & \\
\hline $\begin{array}{l}\text { The educator holds professional responsibili- } \\
\text { ty for each child in his class. }\end{array}$ & & & & & .748 & & \\
\hline $\begin{array}{l}\text { The educator has to set up rules together } \\
\text { with children; they also need to agree about } \\
\text { the consequences of not following the } \\
\text { agreement. }\end{array}$ & & & & & .725 & & \\
\hline $\begin{array}{l}\text { The educator is responsible for effective } \\
\text { communication with families. }\end{array}$ & & & & & .646 & & \\
\hline $\begin{array}{l}\text { Differentiated activities provide better possi- } \\
\text { bilities for all children in the class. }\end{array}$ & & & & & .576 & & \\
\hline $\begin{array}{l}\text { Difficulties that arise in educational work } \\
\text { should be accepted as challenges, not prob- } \\
\text { lems. }\end{array}$ & & & & & .562 & & \\
\hline
\end{tabular}




\begin{tabular}{|c|c|c|c|c|c|c|c|}
\hline Item & $F_{1}$ & $\mathrm{~F}_{2}$ & $\mathrm{~F}_{3}$ & $\mathrm{~F}_{4}$ & $\mathrm{~F}_{5}$ & $F_{6}$ & $\mathrm{~F}_{7}$ \\
\hline $\begin{array}{l}\text { Inclusion requires constant reflection and } \\
\text { changes of one's teaching practice. }\end{array}$ & & & & & & .786 & \\
\hline $\begin{array}{l}\text { The educator needs to know and use differ- } \\
\text { ent methods and strategies of teaching and } \\
\text { learning. }\end{array}$ & & & & & & .766 & \\
\hline $\begin{array}{l}\text { Reflective practice allows for professional } \\
\text { development and development of personal } \\
\text { pedagogy. }\end{array}$ & & & & & & .723 & \\
\hline $\begin{array}{l}\text { Team work supports the educator's profes- } \\
\text { sional development. }\end{array}$ & & & & & & .619 & \\
\hline $\begin{array}{l}\text { The educator has to identify and use the } \\
\text { most effective response in critical situations. }\end{array}$ & & & & & & .544 & \\
\hline $\begin{array}{l}\text { The educator should use role play to teach } \\
\text { children social skills. }\end{array}$ & & & & & & & .792 \\
\hline $\begin{array}{l}\text { The educator has to foster the child's inde- } \\
\text { pendence, autonomy and self-control. }\end{array}$ & & & & & & & .732 \\
\hline $\begin{array}{l}\text { Promoting positive behaviour in the group } \\
\text { is more effective than pointing out negative } \\
\text { behaviour. }\end{array}$ & & & & & & & .651 \\
\hline
\end{tabular}

Factor 1 consisted of 5 items with factor loadings form .837 to .631 and accounted for most of the total variance of $36.90 \%$. The item analysis suggested that the factor measures the belief about the importance of teamwork, cooperation and partnership with parents, families, educators and other professionals, so we named it Team working and cooperation with others. One of the key issues in the development of individual and collective competences for inclusive education concerns co-operation and dialogue among contributors. Collaborative approaches and joint work enhance the effectiveness of education (Donnelly \& Kyriazopoulo, 2014).

Factor 2 also consisted of 5 items and it accounted for $5.50 \%$ of variance. The factor loadings varied from .824 to .610 . The factor included items connected with the system of inclusive education, the acts, procedures, rights, etc. It $t$ was labelled Implementing knowledge about inclusive education and support. Although the educator has close professional relations with the parents, it is very important that he is well informed about the legislation and policy that supports inclusive education and also about the organisation of provision and practice to improve support for all children. 
Factor 3 consisted of 4 items and it accounted for $5.44 \%$ of variance. The factor loadings ranged from .821 to .658 . Since the items refer to the educator who is challenged by changes and learns from SEN children and colleagues in order to be more effective in inclusive practice, we labelled the factor Reflecting on and learning from inclusive practice. The inclusive educator should be a reflective practitioner who is able to perform action research as a tool for critical reflection aimed to develop, change and improve inclusive practice in education (Lloyd, 2002).

Factor 4 encompassed 5 items with loadings from .827 to .704 and it accounted for $4.47 \%$ of variance. Items which load factor 4 indicate that the educator is not only a teacher teaching children in the classroom. They indicate the educator as a researcher, evaluator and professional who is familiar with other related professions and his/her students' backgrounds. We named the factor Optimising challenges and interdisciplinary approach. Educational staff and professionals from a range of disciplines working together may form a good network around children with the capacity to meet a range of support needs (Donnelly \& Kyriazopoulo, 2014). Such networks create an inclusive and learning environment where everyone can benefit and learn from diversity.

Factor 5 consisted of 5 items, which explained $4.14 \%$ of variance. The factor loadings ranged from .748 to .562 . Since the items refer to the educator's responsibility in various educational situations, we named this factor Accepting professional responsibility for each child's development. One of the significant inclusive education tasks is to highlight the responsibility of schools and educators to create environments that are respectful to children's rights and ensure learning and participation for all children (Hollenweger, Hunt \& Sabani, 2015).

Factor 6 encompassed 5 items with loadings from .786 to .544 , which together accounted for $3.78 \%$ of variance. The items refer to the educator as a professional who reflects on and changes his/her practice, teaching methods and strategies and who is proactive. The factor was named Promoting resilience and professionalism. Valenčič Zuljan and Kiswarday (2015) described a resilient educator as a qualified professional who is able to create a sustainable learning environment that enables the optimal educational and personal development of each student and fosters the student's resilience. Over the course of interpersonal influences of personal and social views, a resilient educator continuously improves his/her own professional development and constructively changes the environment.

Factor 7 consisted of 3 items, which accounted for $3.57 \%$ of variance, with loading varying from .792 to .651 . The items suggest the educator should empower children's skills, be it individual or social, to help children become more self-motivated and responsible for their actions, so the factor was named Empowering children's 
life skills. Early childhood is also crucial in the development of one's own belief systems that further on impact on individual feelings of self-worth, self-esteem and self-efficacy. Szente (2007) stresses that enriching children's social-emotional development and teaching various strategies for changing negative thoughts into positives, creating affirmations, designing action plans and goal-setting enables both educators and parents to enhance children with essentials for their success in school and later on in life.

\section{Reliability}

Table 2. Cronbach's alpha for the factors and the InComSEdu

\begin{tabular}{lcccccccc}
\hline \multicolumn{1}{c}{ Subscale } & F1 & F2 & F3 & F4 & F5 & F6 & F7 & InComSEdu* $^{*}$ \\
\hline $\begin{array}{l}\text { Number of } \\
\text { items }\end{array}$ & 5 & 5 & 4 & 5 & 5 & 5 & 3 & 32 \\
\hline $\begin{array}{l}\text { Cronbach's } \\
\text { alpha }\end{array}$ & .799 & .839 & .810 & .819 & .726 & .789 & .719 & .946 \\
\hline
\end{tabular}

* Separate items

Cronbach's alpha for the 32 item scale $(\alpha=.946)$ demonstrates high internal consistency. Analysing the internal consistency of the subscales, we found three of them very highly reliable, i.e.: Implementing knowledge about inclusive education and support $\left(\mathrm{F}_{2}\right)(\alpha=.839)$, Reflecting on and learning from inclusive practice $\left(\mathrm{F}_{3}\right)$ $(\alpha=.810)$, and Optimising challenges and interdisciplinary approach $\left(\mathrm{F}_{4}\right)(\alpha=.819)$. Other four subscales demonstrated moderate internal consistency: Team working and cooperation with others $\left(\mathrm{F}_{1}\right)(\alpha=.799)$, Accepting professional responsibility for each child's development $\left(\mathrm{F}_{5}\right)(\alpha=.726)$, Promoting resilience, self-confidence and professionalism $\left(\mathrm{F}_{6}\right)(\alpha=.789)$, and Empowering children's life skills $\left(\mathrm{F}_{7}\right)(\alpha=.719)$.

\section{Conclusion}

The aim of the study was to construct and to validate an inclusive competences scale for educators (InComSEdu). The final version of the scale consists of 32 items, which were based on exploratory factor analysis, computed into 7 factors (or subscales): $\mathrm{F}_{1}$ : Team working and cooperation with others, $\mathrm{F}_{2}$ : Implementing knowledge about inclusive education and support, $\mathrm{F}_{3}$ : Reflecting on and learning from inclusive practice, $\mathrm{F}_{4}$ : Optimising challenges and interdisciplinary approach, 
$\mathrm{F}_{5}$ : Accepting professional responsibility for each child's development, $\mathrm{F}_{6}$ : Promoting resilience, self-confidence and professionalism, and $\mathrm{F}_{7}$ : Empowering children's life skills. The first factor accounted for $36.89 \%$ and the cumulative total explained $63 \%$ of variance. The reliability values of factors ranged from .719 to .839 . Thus, we can conclude that the scale has excellent validity and satisfying reliability. The results indicate the InComSEdu could be useful as a reference tool for further research on inclusive competences of various ranges of educators. The possible generalizations based on this study are limited as the participants belong to the Slovenian educational environment. In the future, the reasonable direction seems to be to enlarge the size and the heterogeneity of the sample and also to include educators from other countries and put the study into the international context. However, the latter does not impede the scale usefulness as a tool for personal evaluation and targeted development of inclusive competences of educators in preschool settings.

\section{References}

Field, A. (2005). Discovering Statistics using SPSS. London: Sage.

Ainscow, M. (2005). Developing inclusive education systems: what are the levers for change?, Journal of educational change, 6 (2), 109-124.

Baráth, T. (2013). Methodology of the competency framework development; in M. Schratz, M. (ed.): The Art and Science of Leading a School: Cental5: A Central European View on Competencies for School Leadership: Final Report of the Project (31-65). Budapest: Tempus Public Foundation.

Cencič, M., Istenič Starčič, A., Borota, B. (2012). Teacher competencies for incorporating ICT into classroom practice: a survey from Slovenia. Pedagogika, 3 (4), 232-246

Cook, B.G. (2001). A comparison of teachers' attitudes toward the included students with mild and severe disabilities, Journal of Special Education, 3 (4), 203.

Cook, B.G. (2002). Inclusive attitudes, strengths, and weaknesses of pre-service general educators enrolled in a curriculum infusion teacher preparation program. Teacher Education and Special Education: The Journal of the Teacher Education Division of the Council for Exceptional Children, 25 (3), 262-277.

Creswell, J.W. (2014). Research Design: Qualitative, Quantitative, and Mixed Methods Approaches. London: Sage.

Donnelly, V., \& Kyriazopoulo, M. (2014). Organisation of Provision to Support Inclusive Education - Summary Report. Odense, Denmark: European Agency for Special Needs and Inclusive Education. 
Emam, M.M. \& A.H. Mohamed (2011). Preschool and primary school teachers' attitudes towards inclusive education in Egypt: The role of experience and self-efficacy, ProcediaSocial and Behavioural Sciences, 29, 976-985.

Forlin, C., Loreman, T., Sharma, U., \& Earle, C. (2009). Demographic differences in changing pre-service teachers' attitudes, sentiments and concerns about inclusive education. International Journal of Inclusive Education, 13(2), 195-209.

Hollenweger, J., Hunt, P.F. \& Sabani, N. (2015). Inclusive Education: Vision, Theory and Concepts. UNICEF ToT Modules on Inclusive Education. Module 1. United Nations Children's Fund.

Lepičnik Vodopivec, J. \& Vujičić, L. (2010). The Development of Professional Competencies: the Educator as a Reflective Practitioner in Tertiary Education, Scientia paedagogica experimentalis, 47 (1), 1, 111-130.

Lloyd, C. (2002). Developing and changing practice in special educational needs through critically reflective action research: A case study. European Journal of Special Needs Education, 17(2), 109-127.

MacFarlane, K. \& L. Marks Woolfson (2013). Teacher attitudes and behaviour toward the inclusion of children with social, emotional and behavioural difficulties in mainstream schools: An Application of the theory of planned behaviour. Teaching and Teacher Education, 29, 46-52.

Mahat, M. (2008). The Development of a Psychometrically-sound Instrument to Measure Teachers" Multidimensional Attitudes Toward Inclusive Education. International Journal of Special Education. 23 (1), 82-92.

Malinen, O.P., Savolainen, H. \& J. Xu (2012). Beijing in-service teachers' self-efficacy and attitudes towards inclusive education, Teaching and Teacher Education, 28, 526-534.

Marinšek, M. \& Hmelak, M. (2015). Razvoj ključnih kompetenc za profesionalni razvoj študentov predšolske vzgoje. Pedagoška obzorja, 30 (2), 123-137.

Rutar, S. (2012). Inkluzivna praksa iz perspektive osnovnošolskih učiteljev in vzgojiteljev $\mathrm{v}$ vrtcih [Inclusive practice form the perspective of teachers and preschool teachers]; In (ed.): Hozjan, D. in M. Strle: Inkluzija v sodobni šoli (19-34). Koper: Univerzitetna založba Annales.

Sharma, U., Loreman, T.C. Forlin (2012). Measuring teacher efficacy to implement inclusive practices, Journal of Research in Special Educational Needs, 12 (1), 12-21.

Szente, J. (2007). Empowering young children for success in school and in life. Early Childhood Education Journal, 12 (6), 449-453.

Štemberger, T. (2013). Učiteljeva pripravljenost na inkluzijo, [Teachers readiness for inclusion]. Pedagoška obzorja, 28 (3/4), 3-11.

Unianu, E.M. (2012). Teachers' attitudes towards inclusive education, Procedia-Social and Behavioral Sciences, 33, 900-904.

Valenčič Zuljan, M. \& Kiswarday, V.R. (2015). The resilient teacher : the way to reach quality education in contemporary society. In (ed.): Opić, S., Bilić, V., \& Jurčić, M. Odgoj u školi (75-99). Zagreb: Učiteljski fakultet.

Watkins, A. (2012). Teacher education for inclusion: Profile of inclusive teachers. European 
Agency for Development in Special Needs Education. Retrieved, May 24, 2015 from: https://www.european-agency.org/

Weisel, A. \& Dror, O.(2006). School climate, sense of efficacy and Israeli teachers' attitudes toward inclusion of students with special needs, Education, Citizenship and Social Justice, 2, 157-174.

Winter, E.C. (2006). Preparing new teachers for inclusive schools and classrooms, Support for Learning, 21 (2), 85-91. 